\title{
Pengaruh Transformational Leadership dan Perceived Organizational Support terhadap Job Performance: Peran Mediasi Work Engagement
}

\author{
Wahid Mirza Prabowo ${ }^{1}$, Muafi Muafi ${ }^{2 \varpi}$ \\ Universitas Islam Indonesia ${ }^{1,2}$ \\ e-mail: muafi@uii.ac.id
}

\begin{abstract}
The purpose of this study was to examine and analyze the influence of transformational leadership and perceived organizational support on job performance mediated by work engagement on employees of Data Center and Information System of the Ministry of Agriculture in Jakarta, Indonesia. Respondents in this study are 75 employees of the Data Center and Information System of the Ministry of Agriculture. The analytical test tool used is the SMART PLS software with SEM (Structural Equation Modeling) analysis method.The result of this study indicates that transformational leadership has a positive effect on work engagement, perceived organizational support has a positive effect on work engagement, work engagement has a positive effect on job performance, transformational leadership has a positive effect on job performance, perceived organizational support has a positive effect on job performance, transformational support has a positive effect on job performance mediated by work engagement, and perceived organizational support has a positive effect on job performance mediated by work engagement.
\end{abstract}

Keywords: transformational leadership, perceived organizational support, work engagement, job performance

\begin{abstract}
Abstrak
Tujuan penelitian ini adalah untuk menguji dan menganalisis pengaruh transformational leadership dan perceived organizational support terhadap job performance dimediasi work engagement pada pegawai Pusat Data dan Sistem Informasi Kementerian Pertanian berlokasi di Jakarta Indonesia. Responden dalam penelitian ini berjumlah 75 orang yang merupakan pegawai Pusat Data dan Sistem Informasi Kementerian Pertanian. Alat uji analisis yang digunakan adalah software SMARTPLS dengan metode analisis SEM (Structural Equation Modeling). Hasil penelitian ini membuktikan bahwa: transformational leadership berpengaruh positif terhadap work engagement, perceived organizational support berpengaruh positif terhadap work engagement, work engagement berpengaruh positif terhadap job performance, transformational leadership berpengaruh positif terhadap job performance, perceived organizational support berpengaruh positif terhadap job performance, transformational leadership berpengaruh positif terhadap job performance dimediasi work engagement, dan perceived organizational support berpengaruh positif terhadap job performance dimediasi work engagement.
\end{abstract}

Kata kunci: transformational leadership, perceived organizational support, work engagement, job performance 


\section{PENDAHULUAN}

Sumber daya manusia menjadi faktor penting bagi kelangsungan kinerja perusahaan di zaman millennial dengan persaingan yang ketat sekarang ini. Sumber daya manusia yang memiliki kinerja yang baik yang dapat menjadi keunggulan kompetitif bagi perusahaan itu sendiri. Mathis \& Jakson (2002) mengatakan bahwa karyawan merupakan sumber daya yang penting bagi perusahaan karena memiliki bakat, tenaga dan kreativitas yang sangat dibutuhkan oleh perusahaan untuk mencapai tujuannya. Kinerja karyawan yang dicari oleh perusahaan adalah karyawan yang berkinerja tinggi dan memiliki ketergantungan dengan kemampuan, motivasi, dan dukungan organisasi. Pengelolaan sumber daya manusia secara tepat dapat menjadi upaya bagi perusahaan dalam mendapatkan kinerja karyawan yang maksimal. Handoko (2001) mengatakan bahwa pengelolaan sumber daya manusia merupakan hal yang paling penting untuk mencapai tujuan suatu organisasi. Jika karyawan dibina secara efektif, maka akan bermanfaat bagi individu tersebut, organisasi, bahkan masyarakat secara luas. Untuk mendapatkan kinerja karyawan yang maksimal, perusahaan dapat mengupayakan dengan meningkatkan motivasi karyawan. Salah satu cara yang dapat ditempuh adalah dengan menumbuhkan rasa keterlibatan dalam diri karyawan terhadap pekerjaannya. Dengan karyawan memiliki rasa keterlibatan yang tinggi, maka akan berdampak baik terhadap kinerja karyawan. Hal ini didukung penelitian oleh Lai dkk. (2020) yang membuktikan bahwa keterlibatan kerja memiliki pengaruh positif terhadap kinerja karyawan.

Terdapat beberapa faktor yang dapat meningkatkan rasa keterlibatan kerja dalam diri karyawan dan kinerja. Salah satunya adalah adanya penerapan transformational leadership dalam perusahaan. Pemimpin memegang peran penting dalam kelangsungan organisasi. Pemimpin harus dapat memberikan inspirasi bagi karyawannya sehingga akan muncul rasa keterpercayaan, loyalitas, dan respect dari karyawan terhadap pemimpinnya. Akhirnya dengan karyawan akan bekerja secara sukarela dan bekerja lebih dari yang diharapkan oleh organisasi. Yukl (1989) mengatakan bahwa kepemimpinan transformasional adalah gaya kepemimpinan di mana pemimpin mengubah nilai-nilai dasar, kepercayaan, dan sikap pengikut, menginspirasi pengikut untuk menunjukkan kinerja yang lebih besar dari harapan mereka sendiri. Hal ini didukung oleh beberapa penelitian yang menunjukkan adanya pengaruh transformational leadership terhadap work engagement. Seperti penelitian yang dilakukan oleh Datche \& Mukulu (2015) yang dilakukan pada 252 pegawai yang bekerja pada 18 perusahaan di Kenya. Penelitian tersebut menghasilkan temuan adanya pengaruh signifikan transformational leadership terhadap work engagement.

Topik yang menjadi perhatian selanjutnya yakni perceived organizational support yang juga memiliki dampak terhadap keterlibatan kerja dan job performance. Ketika karyawan merasakan bahwa perusahaan telah memberi dukungan yang cukup, maka akan tercipta perceived organizational support yang positif oleh karyawan terhadap perusahaan sehingga karyawan lebih merasa terlibat dalam pekerjaannya. Hal ini didukung penelitian oleh Abed \& Elewa (2016) yang meneliti hubungan perceived organizational support terhadap keterlibatan kerja di mana menghasilkan temuan bahwa perceived organizational support memiliki pengaruh yang positif terhadap keterlibatan kerja.

Penelitian ini dilaksanakan di Kementerian Pertanian Jakarta pada divisi Pusat Data dan Sistem Informasi Pertanian atau yang biasa disingkat Pusdatin. Tugas dari divisi pusat data dan sistem informasi adalah melaksanakan pembinaan, pengolahan, analisis, serta pelayanan dan publikasi data dan informasi pertanian. Tentu saja agar karyawan divisi pusat data dan sistem informasi dapat memenuhi tugas seperti 
yang telah ditetapkan sehingga dibutuhkan sumber daya manusia yang berkualitas yang dapat menghasilkan kinerja pekerjaan yang baik. Penelitian ini penting dilakukan untuk melihat sejauh mana support yang telah diberikan oleh organisasi kepada karyawannya sehingga karyawan merasa lebih terlibat dalam pekerjaannya sehingga dapat menghasilkan kinerja yang baik. Dengan dilakukannya penelitian ini, diharapkan dapat membantu organisasi dalam mewujudkan visi dan misi yang telah ditetapkan.

Kepemimpinan transformasional di Pusdatin Kementerian Pertanian dapat dilihat melalui Pimpinan Pusdatin yang selalu menciptakan suasana kerja dengan semangat kekeluargaan dan membuka informasi secara terbuka dengan pegawai, serta mendukung atau memotivasi pegawainya sekaligus memberi kesempatan kepada pegawai untuk meningkatkan kemampuan dalam rangka pengembangan diri. Hal ini dilakukan dengan memberikan kesempatan karyawan untuk melanjutkan sekolah ke jenjang pendidikan yang lebih tinggi. Dengan suasana kerja yang positif tersebut, diharapkan membuat karyawan merasa menjadi memiliki keluarga besar bernama Pusdatin.

Dukungan organisasi yang diberikan dari perusahaan terhadap pegawai Pusdatin selain gaji pokok adalah beberapa tunjangan yang diberikan kepada pegawai, yang meliputi tunjangan jabatan, tunjangan suami/istri dan dua orang anak untuk yang sudah berkeluarga, tunjangan kesehatan, dan tunjangan kinerja. Tunjangan tersebut tergantung jabatan dari para pegawai. Saat ini terdapat 119 pegawai di lingkungan Pusdatin Kementerian Pertanian. Sebanyak $80 \%$ diantaranya merupakan pejabat fungsional yang terdiri dari $40 \%$ fungsional statistisik, $30 \%$ fungsional pranata komputer, dan $10 \%$ fungsional lainnya di bidang administrasi. Pejabat fungsional yang ingin naik jabatan ke jenjang diatasnya harus mengumpulkan poin minimal yang disyaratkan. Makin besar poin yang diperoleh, makin cepat kenaikan pangkatnya.
Poin tersebut dinilai oleh tim penilai berdasarkan hasil pekerjaan masing-masing pegawai. Hasil penilaian sekaligus menunjukkan tingkat kerajinan atau keaktifan pegawai yang bersangkutan. Seiring meningkatnya pangkat atau jabatan, tunjangan juga akan meningkat sesuai dengan jenjang peningkatannya. Selain tunjangan yang telah disebutkan, ada juga fasilitas lainnya yang diberikan untuk menunjang pengembangan pegawai, yaitu pemberian beasiswa baik dari internal maupun eksternal Pusdatin.

Selain melaksanakan tugas yang sudah menjadi spesialisasi jabatannya, pegawai Pusdatin diberikan kesempatan luas untuk mengembangkan ilmu yang dimilikinya untuk dimanfaatkan oleh pihak lain, seperti menulis buku yang difasilitasi publikasinya pada website Kementerian Pertanian, membimbing pelajar setingkat SLTA yang sedang menyelesaikan tugas akhir, dan membimbing skripsi mahasiswa program studi statistik atau komputer. Dampak positif dari terciptanya suasana kerja yang positif dan dukungan yang diberikan oleh organisasi adalah loyalitas dan totalitas kerja pegawai yang selalu siap 24 jam ketika dibutuhkan tanpa merasa terbebani karena sudah merasa menjadi tanggung jawab bersama.

\section{Hubungan Transformational Leadership terhadap Work Engagement}

Rafferty \& Griffin (2004) menjelaskan transformational leadership adalah pemimpin memberikan motivasi kepada bawahan untuk mencapai kinerja lebih dari yang diharapkan dengan mengubah sikap, kepercayaan, dan nilai-nilai bawahan. Hersey dkk. (1996) mendefinisikan transformational leadership sebagai proses memengaruhi yang disengaja pada seorang individu atau kelompok untuk membawa perubahan yang terputus pada keadaan saat ini dan fungsi organisasi secara keseluruhan. Ditambahkan oleh Hall dkk. (2002), transformational leadership berarti pemimpin memiliki kemampuan untuk membuat orang ingin berubah, berkembang 
dan dapat membuat perusahaan lebih sukses.

Penelitian yang dilakukan oleh Hayati dkk. (2014) bertujuan untuk menganalisis pengaruh transformational leadership terhadap work engagement. Hasil dari penelitiannya membuktikan bahwa transformational leadership memberikan pengaruh positif terhadap work engagement. Hasil serupa juga ditemukan oleh Ghadi dkk. (2013) dan Mustafa \& Kanbur (2018). Hal ini menandakan bahwa pemimpin transformasional menciptakan karyawan yang lebih enerjik, berdedikasi, dan semakin larut dalam pekerjaannya. Datche \& Mukulu (2015) juga melakukan penelitian serupa dengan rseponden pegawai negeri sipil di Kenya. Hasil penelitian serupa juga diukung oleh Arfat dkk. (2017) dan Lai dkk. (2020).

$\mathrm{H}_{1}$ : Terdapat pengaruh positif signifikan transformational leadership terhadap work engagement.

\section{Hubungan Perceived Organizational terhadap Work Engagement}

Perceived organizational support, menurut Eisenberger dkk. (1986), merupakan keyakinan global karyawan bahwa organisasi menghargai kontribusi dan peduli terhadap kesejahteraan karyawan. Rhoades \& Eisenberger (2002) mendefinisikan perceived organizational support adalah sejauh mana organisasi menilai kontribusi karyawan dan kepedulian terhadap kesejahteraan mereka dan membalas dukungan yang dirasakan tersebut dengan peningkatan kinerja karyawan. Ditambahkan oleh Hellman (2006, dalam Köse, 2016) bahwa pekerja mempersepsikan penerimaan kontribusi yang mereka berikan kepada organisasi sebagai hasil dari usaha dan perhatian organisasi terhadap kesejahteraan pekerjanya.

Abed \& Elewa (2016) melakukan penelitian yang menganalisis hubungan perceived organizational support, work engagement, dan organizational citizenship behavior. Hasilnya menunjukkan adanya hubungan yang signifikan perceived organizational support dengan work engagement. Penelitian serupa dilakukan oleh Wan \& Saidin (2018) pada staf dari 10 universitas di China. Hasil dari penelitiannya juga menunjukan bahwa perceived organizational support berpengaruh positif terhadap work engagement. Hubungan ini juga didukung oleh Köse (2016) dan Karatepe \& Aga (2016). Dalam temuan lain, Nasurdin dkk. (2018) menganalisis pengaruh peer support, supervisory support, dan organizational support pada job performance dengan peran mediasi work engagement. Penelitiannya menghasilkan temuan bahwa perceived organizational support berkaitan positif dengan work engagement.

$\mathrm{H}_{2}$ : Terdapat pengaruh perceived organizational support terhadap work engagement.

\section{Hubungan Work Engagement terhadap Job Performance}

Saks (2006) mendefinisikan work engagement sebagai konstruk yang terdiri dari komponen kognitif, emosional, dan perilaku yang terkait dengan kinerja peran individu. Menurut Schaufeli \& Bakker (2004) work engagement merupakan keadaan aktif yang terkait dengan pekerjaan yang positif yang ditandai dengan vigor, dedication, dan absorption. Kahn (1990, dalam Kinicki \& Fugate, 2018) menambahkan bahwa karyawan yang memiliki work engagement berarti memiliki keadaan untuk mengidentifikasikan dirinya dengan pekerjaannya, yaitu bekerja dan mengekspresikan diri mereka secara fisik, kognitif, dan emosional dalam pekerjaan mereka.

Nasurdin dkk. (2018) melakukan penelitian dengan tujuan untuk menganalisis hubungan peer support, supervisory support, dan organizational support pada job performance dengan mediasi work engagement. Hasil penelitiannya menunjukkan adanya pengaruh positif work engagement terhadap 
job performance. Hasil tersebut didukung juga oleh Lai dkk. (2020) dengan responden perawat dari dua rumah sakit yang berada di Taiwan. Selain itu, Karatepe \& Aga (2016) menghasilkan temuan yang sama dengan responden pada karyawan bank di Cyprus Utara.

$\mathrm{H}_{3}$ : Terdapat pengaruh work engagement terhadap job performance.

\section{Hubungan Transformational Leadership terhadap Job Performance}

Menurut Manzoor dkk. (2019), kinerja adalah tindakan dan perilaku yang relevan dengan tujuan organisasi, yang berada di bawah kendali karyawan. Motowidlo \& Kell (2013) mendefinisikan job performance sebagai nilai total yang diharapkan diberikan kepada organisasi dari perilaku selama periode waktu yang ditentukan oleh organisasi. Ditambahkan oleh Babin \& Boles (1998) bahwa job performance adalah tingkat produktivitas individu karyawan yang saling berhubung pada rekan-rekannya pada beberapa perilaku dan outcomes yang terkait dengan pekerjaannya.

Penelitian yang dilakukan oleh Chandrasekara (2019) dan Manzoor (2019) menghasilkan temuan bahwa kualitas transformational leadership memiliki pengaruh signifikan terhadap job performance. Temuan riset ini juga didukung oleh Lu \& Lin (2014) yang melakukan penelitian pada karyawan perusahaan pelayaran kontainer di Taiwan.

$\mathrm{H}_{4}$ : Terdapat pengaruh transformational leadership terhadap job performance.

\section{Hubungan Perceived Organizational Support terhadap Job Performance}

Arshadi \& Hayavi (2013) dalam risetnya menghasilkan temuan bahwa perceived organizational support berpengaruh positif terhadap work engagement. Hasil riset ini ternyata juga didukung oleh Joorsara dkk. (2015) dan Karatepe \& Aga (2016), di mana karyawan yang memperoleh dukungan dari organisasi cenderung akan memiliki kinerja kerja yang bagus dan meningkat.
$\mathrm{H}_{5}$ : Terdapat pengaruh perceived organizational support terhadap job performance.

\section{Hubungan Transformational Leadership terhadap Job Performance Dimediasi Work Engagement}

Peneliti Lai dkk. (2020) menghasilkan temuan bahwa kepemimpinan transformasional dapat meningkatkan kinerja pekerjaan karyawan dengan mendorong keterlibatan karyawan sehingga karyawan bekerja lebih dari yang diharapkan organisasi. Penelitian serupa dilakukan oleh Buil dkk. (2018) pada karyawan hotel bintang tiga, empat, dan lima di Spanyol dengan hasil riset yang menyimpulkan bahwa work engagement memediasi hubungan transformational leadership dengan job performance. Hasil tersebut juga didukung oleh Al-Amin (2017).

$\mathrm{H}_{6}$ : Terdapat pengaruh transformational leadership terhadap job performance dimediasi work engagement.

\section{Hubungan Perceived Organizational Support terhadap Job Performance Dimediasi Work Engagement}

Karatepe \& Aga (2016) telah meneliti karyawan bank di Cyprus Utara dengan hasil temuan menyimpulkan bahwa work engagement memediasi pengaruh perceived organizational support pada job performance. Selanjutnya, Nasurdin (2018) dan Rubel \& Kee (2013) melakukan penelitian pada perawat rumah sakit di Malaysia dengan hasil yang sama. Perceived organizational support dapat meningkatkan kinerja karyawan dengan mendorong keterlibatan karyawan sehingga karyawan bekerja lebih dari yang diharapkan organisasi.

$\mathrm{H}_{7}$ : Terdapat pengaruh perceived organizational support terhadap job performance dimediasi work engagement. 


\section{METODE PENELITIAN}

Penelitian ini menggunakan metode penelitian kuantitatif. Metode kuantitatif yaitu menguji teori secara obyektif dengan menguji keterkaitan antara beberapa variabel. Variabel-variabel tersebut diukur dengan menggunakan instrumen sehingga hasil dari penghitungan tersebut dapat dianalisis menggunakan prosedur statistikal. Menurut Creswell (2009), metode kuantitatif adalah metode untuk menguji teori-teori objektif dengan memeriksa hubungan antar variabel. Variabel-variabel ini dapat diukur menggunakan instrumen, sehingga data dapat dianalisis menggunakan prosedur statistik. Bentuk final dari penelitian ini memiliki struktur pengantar, literatur dan teori, metode, hasil, dan diskusi.

Populasi dalam penelitian ini adalah seluruh karyawan Divisi Pusdatin di Kementerian Pertanian Republik Indonesia yang berjumlah 75 orang dan sekaligus sebagai sampel dalam penelitian sehingga penelitian ini disebut sebagia penelitian sensus.

\section{HASIL DAN PEMBAHASAN}

Dari hasil kuesioner yang dikembalikan, didapat hasil jawaban responden mengenai jenis kelamin, umur, dan pendidikan terakhir responden. Dapat disimpulkan bahwa karyawan Pusdatin Kementerian Pertanian Republik Indonesia paling banyak adalah perempuan sebanyak 47 orang atau sebesar 63\%, sedangkan karyawan laki-laki sebanyak 28 orang atau $37 \%$. Umur responden paling banyak antara 48-58 tahun yaitu sebesar $42,7 \%$, urutan kedua yaitu antara 26-36 tahun sebesar 29,3\%, dan terakhir antara 37-47 tahun sebesar $28 \%$. Hal ini menunjukkan bahwa karyawan pada Divisi Pusdatin di Kementerian Pertanian Republik Indonesia termasuk dalam kategori usia senior. Berdasarkan pendidikan terakhir dapat diketahui paling banyak karyawan tamat $\mathrm{S} 1$ yaitu sebesar $45,3 \%$, diikuti dengan tamat SLTA sebesar 12\%, D3 sebesar 5,3\%, S2 sebesar 34,7\%, dan S3 sebesar 2,7\%.

\section{Pengujian Validitas dan Reliabilitas}

Discriminant Validity digunakan sebagai pengujian validitas berasal dari nilai cross loading yang berguna untuk mengetahui apakah konstruk memiliki diskriminan yang memadai dengan cara membandingkan nilai loading pada konstruk yang dituju harus lebih besar dibandingkan dengan nilai yang lain. Dengan standar nilai untuk setiap konstruk harus lebih besar dari 0,5. Hasil cross loading menunjukkan bahwa setiap indikator berkorelasi lebih tinggi dengan konstruknya masing-masing dibandingkan dengan konstruk lainnya, sehingga dapat dikatakan memiliki validitas diskriminan yang baik.

Selain validitas konstruk, dilakukan juga uji reliabilitas konstruk yang diukur dengan composite reliability dari blok indikator yang mengukur konstruk. Konstruk dinyatakan reliabel apabila nilai composite reliability di atas 0,70 (Ghozali \& Latan, 2015). Hasil pengujian reliabilitas semua variabel menunjukkan nilai composite reliability lebih dari 0,7 . Dapat disimpulkan bahwa variabel-variabel yang diujikan reliabel sehingga dapat dilanjutkan untuk menguji model struktural.

Pengujian inner model adalah untuk mengevaluasi hubungan konstruk laten atau variabel yang telah dihipotesiskan (Ghozali \& Latan, 2015). Pengujian inner model dilakukan untuk melihat hubungan antara konstruk dan nilai signifikansinya serta nilai $R$-square. Nilai $R$-square digunakan untuk menilai pengaruh variabel independen terhadap variabel dependen apakah mempunyai pengaruh yang substantif. Sementara itu, Q-square berfungsi untuk mengukur relevansi prediksi dalam model penelitian. Hasil olah data penelitian ini memiliki nilai $R$-square sebesar 0,482 pada variabel work engagement yang menandakan bahwa kemampuan model pada variabel transformational leadership dan perceived organizational support dalam menjelaskan variabel work engagement adalah sebesar $48,2 \%$ dan sisanya dijelaskan oleh variabel lain. Nilai $R$-square sebesar 0,574 pada 
variabel job performance menunjukkan kemampuan model pada variabel transformational leadership, perceived organizational support dan work engagement dalam menjelaskan variabel job performance sebesar 57,4\% dan sisanya dijelaskan oleh variabel lain.

\section{Pengujian Hipotesis}

Hasil olah data uji outer model dapat dilihat pada Gambar 1. Hasil pengolahan data pengujian hubungan langsung antar variable dapat dilhat pada Tabel 1 . Sedangkan hasil uji mediasi dapat dilihat pada Tabel 2.

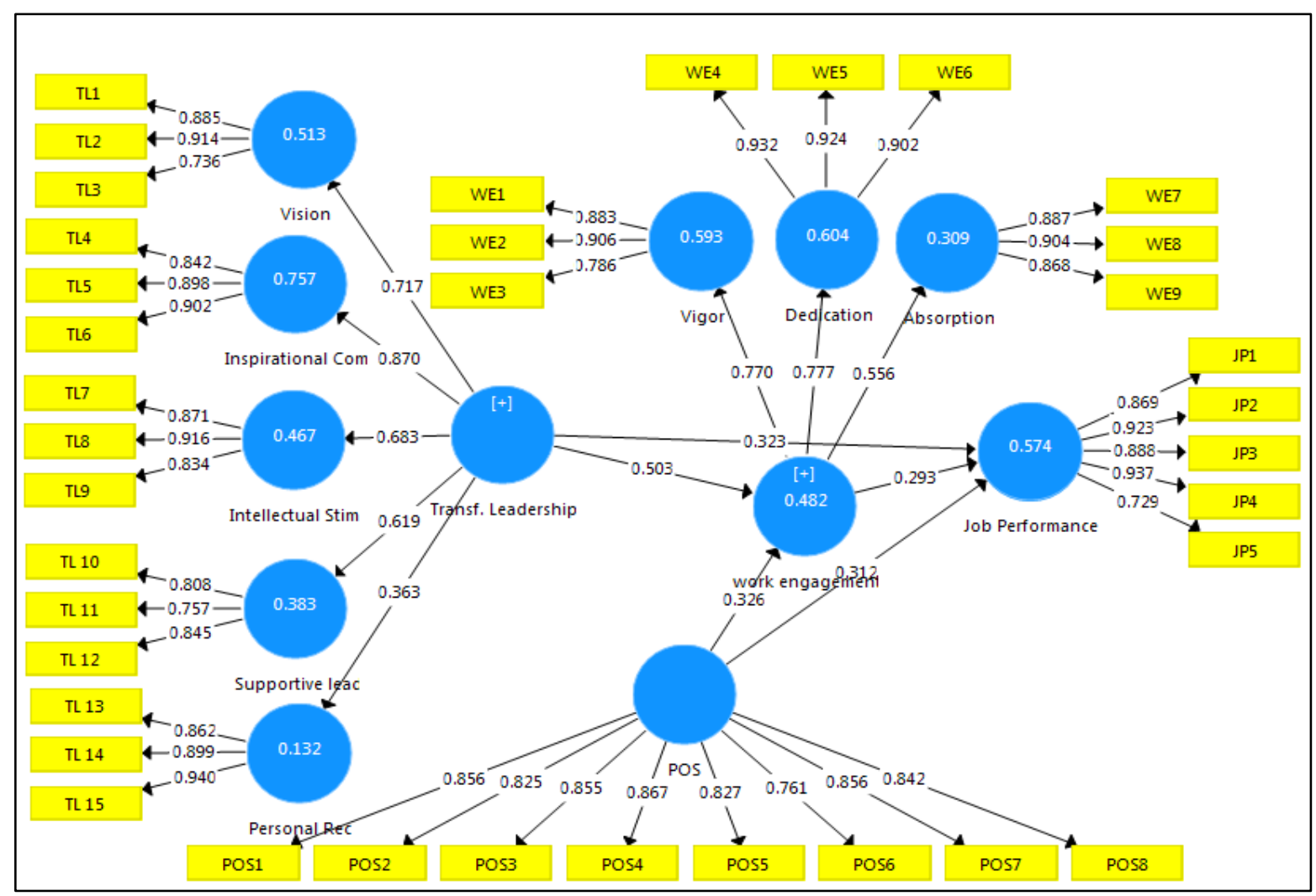

Gambar 1. Hasil Olah Data Uji Outer Model

Tabel 1. Hasil Pengujian Hubungan Langsung Antar Variabel

\begin{tabular}{lcccc}
\hline & $\begin{array}{c}\text { Original } \\
\text { Sample }(\mathrm{O})\end{array}$ & $\begin{array}{c}\text { t Statistics } \\
(|\mathrm{O} / \mathrm{STDEV}|)\end{array}$ & $\mathrm{P}$ Values & Keterangan \\
\hline Transf. leadership $->$ Work engagement & 0,503 & 5,791 & $0,000^{*}$ & $\mathrm{H}_{1}$ diterima \\
POS -> Work engagement & 0,326 & 3,090 & $0,002^{*}$ & $\mathrm{H}_{2}$ diterima \\
Work engagement $\rightarrow$ Job performance & 0,293 & 2,927 & $0,004^{*}$ & $\mathrm{H}_{3}$ diterima \\
Transf. Leadership $->$ Job performance & 0,470 & 4,834 & $0,000^{*}$ & $\mathrm{H}_{4}$ diterima \\
POS -> Job performance & 0,407 & 4,341 & $0,000^{*}$ & $\mathrm{H}_{5}$ diterima \\
\hline
\end{tabular}

Keterangan: $*$ sign $=$ alpha 0,05

Table 2. Pengaruh Mediasi

\begin{tabular}{lcccc}
\hline \multirow{2}{*}{ Pola hubungan Variabel } & \multicolumn{4}{c}{ Indirect Effects } \\
\cline { 2 - 5 } & Koefisien & t Hitung & $\mathrm{P}$ Values & Keterangan \\
\hline Transf. leadership -> Work engagement -> Job performance & 0.147 & 2.466 & $0,014^{*}$ & $\mathrm{H}_{6}$ diterima \\
POS -> Work engagement $->$ Job performance & 0.095 & 2.221 & $0,027^{*}$ & $\mathrm{H}_{7}$ diterima \\
\hline
\end{tabular}

Keterangan: $*$ sign $=$ alpha 0,05 


\section{Pengaruh Transformational Leadership terhadap Work Engagement}

Hasil penelitian menunjukkan bahwa transformational leadership mempunyai pengaruh positif dan signifikan terhadap work engagement pada pegawai Divisi Pusdatin di Kementerian Pertanian Republik Indonesia, dibuktikan dengan nilai $p$ value sebesar 0,000 lebih kecil dari 0,05 maka Ho ditolak dan $\mathrm{Ha}$ diterima artinya transformational leadership secara parsial mempunyai pengaruh yang signifikan terhadap work engagement. Adanya pengaruh positif transformational leadership terhadap work engagement menunjukkan bahwa makin baik transformational leadership, makin tinggi work engagement ( $\mathrm{H}_{1}$ diterima). Hasil penelitian ini didukung dengan penelitian yang dilakukan Arfat dkk. (2017), Hayati dkk. (2014), dan Ghadi dkk. (2013).

Hasil analisis deskriptif menunjukkan penilaian terendah pada indikator inspirational communication dengan ratarata sebesar 2,00. Inspirational communication merupakan ekspresi pesan positif dan menggembirakan tentang organisasi, dan pernyataan yang membangun motivasi dan kepercayaan diri. Pimpinan dapat mengatakan hal-hal yang membuat karyawan bangga menjadi bagian dari organisasi, mengatakan hal-hal positif tentang unit kerja, dan mendorong orang untuk melihat perubahan lingkungan sebagai situasi yang penuh dengan peluang.

\section{Pengaruh Perceived Organizational Support terhadap Work Engagement}

Hasil penelitian menunjukkan bahwa perceived organizational support mempunyai pengaruh positif dan signifikan terhadap work engagement pada pegawai Divisi Pusdatin di Kementerian Pertanian Republik Indonesia. Hal ini terbukti nilai $p$ value sebesar 0,002 yang lebih kecil dari 0,05 sehingga Ho ditolak dan Ha diterima. Hal ini berarti bahwa perceived organizational support secara parsial mempunyai pengaruh yang signifikan terhadap work engagement. Adanya pengaruh positif perceived organizational support terhadap work engagement, menunjukkan bahwa makin baik perceived organizational support, makin tinggi work engagement $\left(\mathrm{H}_{2}\right.$ diterima). Hasil penelitian ini didukung dengan penelitian yang dilakukan oleh Nasurdin dkk. (2018), Karatepe \& Aga (2016), dan Köse (2016).

Hasil analisis deskriptif menunjukkan pegawai pada Divisi Pusdatin di Kementerian Pertanian Republik Indonesia masih banyak yang memberikan penilaian sedang atau cukup pada variabel perceived organizational support, yaitu sebesar $41,3 \%$. Hal ini menandakan karyawan menerima dukungan organisasi yang diberikan sehingga meningkatnya tingkat keterikatan kerja pegawai dapat terlihat ketika karyawan siap 24 jam ketika dibutuhkan oleh organisasi tanpa ada rasa beban karena sudah merasa menjadi tanggung jawab bersama. Persepsi dukungan organisasional dapat meningkatkan minat karyawan dalam pekerjaannya dengan meningkatkan kompetensi yang dirasakan karyawan karena kompetensi yang dirasakan berhubungan dengan minat. Oleh karena itu, organisasi sebaiknya peduli dengan opini dan masukan yang disampaikan oleh pegawai, dan memperhatikan kesejahteraan pegawai.

\section{Pengaruh Work Engagement terhadap Job Performance}

Hasil penelitian menunjukkan bahwa work engagement mempunyai pengaruh positif dan signifikan terhadap job performance pada pegawai Divisi Pusdatin di Kementerian Pertanian Republik Indonesia. Hal ini dibuktikan dengan nilai $p$-value sebesar 0,004 yang lebih kecil dari 0,05 sehingga Ho ditolak dan $\mathrm{Ha}$ diterima. Artinya, work engagement secara parsial mempunyai pengaruh yang signifikan terhadap job performance. Adanya pengaruh positif work engagement terhadap job performance menunjukkan bahwa makin baik work engagement, makin tinggi job performance $\left(\mathrm{H}_{3}\right.$ diterima). Hasil 
penelitian ini didukung dengan penelitian yang dilakukan Nasurdin dkk. (2018), Lai dkk. (2020), dan Karatepe \& Aga (2016).

Hasil analisis deskriptif menunjukkan pegawai Divisi Pusdatin di Kementerian Pertanian Republik Indonesia memberikan penilaian tertinggi pada indikator dedication. Dedication ditandai dengan sangat terlibat dalam suatu pekerjaan dan mengalami rasa antusias, bangga, dan tertantang pada pekerjaannya. Hal ini menandakan bahwa karyawan memiliki tingkat keterikatan kerja yang tinggi sehingga cenderung akan menunjukkan kinerja yang baik.

\section{Pengaruh Transformational Leadership terhadap Job Performance}

Hasil penelitian menunjukkan bahwa transformational leadership mempunyai pengaruh positif dan signifikan terhadap job performance pada pegawai Divisi Pusdatin di Kementerian Pertanian Republik Indonesia. Hal ini terbukti dari nilai $p$-value sebesar 0,000 yang lebih kecil dari 0,05 sehingga Ho ditolak dan $\mathrm{Ha}$ diterima. Artinya, transformational leadership secara parsial mempunyai pengaruh yang signifikan terhadap job performance. Adanya pengaruh positif transformational leadership terhadap job performance, menunjukkan bahwa makin baik transformational leadership, makin tinggi job performance $\left(\mathrm{H}_{4}\right.$ diterima). Hasil penelitian ini didukung dengan penelitian yang dilakukan oleh Chandrasekara (2019), Lu \& Lin (2014), dan Manzoor dkk. (2019).

Kepemimpinan transformasional dapat meningkatkan kinerja pegawai. Seperti yang dilakukan pemimpin di Pusdatin Kementerian Pertanian, di mana pemimpin memperhatikan kebutuhan setiap karyawannya, mendengar kebutuhan dan keinginan karyawannya, serta bertindak sebagai mentor, memberi kesempatan anggotanya mengembangkan diri sehingga pemimpin dapat menciptakan lingkungan dan iklim organisasi yang mendukung. Pemimpin dapat menunjukan keteguhan hati, kesiapan dalam mencapai tujuan, mengambil tanggung jawab penuh atas tindakannya, dan menunjukan kepercayaan diri terhadap visi, serta memberikan penghargaan atas prestasi bawahannya.

\section{Pengaruh Perceived Organizational Support terhadap Job Performance}

Hasil penelitian menunjukkan bahwa perceived organizational support mempunyai pengaruh positif dan signifikan terhadap job performance pada pegawai Divisi Pusdation di Kementerian Pertanian Republik Indonesia. Hal ini terbukti dari nilai $p$-value sebesar 0,000 yang lebih kecil dari 0,05 sehingga Ho ditolak dan $\mathrm{Ha}$ diterima. Artinya, perceived organizational support secara parsial mempunyai pengaruh yang signifikan terhadap job performance. Adanya pengaruh positif perceived organizational support terhadap job performance menunjukkan bahwa makin baik perceived organizational support, makin tinggi job performance $\left(\mathrm{H}_{5}\right.$ diterima). Hasil penelitian ini didukung dengan penelitian yang dilakukan oleh Arshadi \& Hayavi (2013), Joorsara dkk. (2015), dan Karatepe \& Aga (2016).

Persepsi dukungan organisasi dapat meningkatkan standar aktivitas pekerjaan dari tanggung jawab yang diberikan, sehingga dapat menguntungkan organisasi. Persepsi pegawai terhadap dukungan organisasi yang diterimanya akan makin positif atau meningkat dikarenakan organisasi memberikan perhatian karyawan, diantaranya organisasi peduli terhadap kebutuhan karir karyawan, seperti dengan memberikan beasiswa dan organisasi peduli dengan kebutuhan keuangan karyawan, serta menghargai kontribusi karyawan dalam hal kompensasi dan imbalan kerja.

\section{Pengaruh Transformational Leadership terhadap Job Performance Dimediasi Work Engagement}

Hasil penelitian menunjukkan bahwa transformational leadership mempunyai pengaruh positif dan signifikan terhadap job performance yang dimediasi variabel work 
engagement pada pegawai Divisi Pusdatin di Kementerian Pertanian Republik Indonesia. Hal ini terbukti dari nilai $p$-value sebesar 0,014 yang lebih kecil dari 0,05 sehingga Ho ditolak dan Ha diterima. Artinya, transformational leadership secara parsial mempunyai pengaruh yang signifikan terhadap job performance melalui work engagement. Makin baik transformational leadership, makin tinggi work engagement dan pada akhirnya kinerja pegawai juga akan semakin meningkat $\left(\mathrm{H}_{6}\right.$ diterima). Hasil penelitian ini didukung dengan penelitian yang dilakukan oleh Lai dkk. (2020), Buil dkk. (2018), dan Al-Amin (2017).

Pemimpin di kantor Pusdatin Kementerian Pertanian selalu menciptakan suasana kerja dengan semangat kekeluargaan dan membuka informasi secara terbuka dengan pegawai, serta mendukung atau memotivasi pegawainya sekaligus memberi kesempatan kepada pegawai untuk meningkatkan kemampuan dalam rangka pengembangan diri, melalui melanjutkan sekolah ke jenjang pendidikan yang lebih tinggi. Suasana kerja yang positif tersebut membuat karyawan merasa memiliki keluarga besar bernama Pusdatin. Dampak positif dari hal ini adalah tingkat keterlibatan kerja pegawai makin meningkat, contohnya pegawai selalu siap 24 jam ketika dibutuhkan tanpa merasa terbebani karena sudah merasa menjadi tanggung jawabnya. Dengan karyawan memiliki rasa keterlibatan yang tinggi, maka akan berdampak baik terhadap kinerja karyawan.

\section{Pengaruh Perceived Organizational Support terhadap Job Performance Dimediasi Work Engagement}

Hasil penelitian menunjukkan bahwa perceived organizational support mempunyai pengaruh positif dan signifikan terhadap job performance yang dimediasi variabel work engagement pada pegawai Divisi Pusdatin di Kementerian Pertanian Republik Indonesia. Hal ini terbukti dari nilai $p$-value sebesar 0,027 yang lebih kecil dari 0,05 sehingga Ho ditolak dan $\mathrm{Ha}$ diterima. Artinya, perceived organizational support secara parsial mempunyai pengaruh yang signifikan terhadap job performance melalui work engagement. Makin baik perceived organizational support, makin tinggi work engagement dan pada akhirnya kinerja pegawai juga akan semakin meningkat $\left(\mathrm{H}_{7}\right.$ diterima). Hasil penelitian ini didukung dengan penelitian yang dilakukan oleh Karatepe \& Aga (2016), Nasurdin dkk. (2018), dan Rubel \& Kee (2013).

Dukungan organisasi yang diberikan dari perusahaan terhadap pegawai, selain gaji pokok, adalah beberapa tunjangan yang diberikan kepada pegawai. Tunjangan tersebut meliputi tunjangan jabatan, tunjangan suami/istri dan anak untuk yang sudah berkeluarga, tunjangan kesehatan, dan tunjangan kinerja. Pegawai juga diberikan kesempatan luas untuk mengembangkan ilmu yang dimilikinya untuk dimanfaatkan oleh pihak lain, seperti menulis buku yang difasilitasi publikasinya didalam website Kementerian Pertanian. Ketika karyawan merasakan bahwa perusahaan telah memberi dukungan yang cukup, maka akan tercipta persepsi oleh karyawan terhadap perusahaan sehingga karyawan lebih merasa terlibat dalam pekerjaannya sehingga kinerjanya juga akan meningkat.

\section{SIMPULAN DAN SARAN}

Berdasarkan hasil analisis data dan pembahasan maka dapat ditarik beberapa kesimpulan yaitu terdapat pengaruh positif transformational leadership terhadap work engagement pada karyawan Pusdatin Kementerian Pertanian. Hal ini dibuktikan dengan koefisien jalur positif sebesar 0,503 dan thitung sebesar 5,791 dan signifikansi sebesar $0,000<0,05$. Terdapat pengaruh positif perceived organizational support terhadap work engagement pada karyawan Pusdatin Kementerian Pertanian. Hal ini dibuktikan dengan koefisien jalur positif sebesar 0,326 dan thitung sebesar 3,090 dan signifikansi sebesar $0,002<0,05$. Terdapat 
pengaruh positif work engagement terhadap job performance pada karyawan Pusdatin Kementerian Pertanian. Hal ini dibuktikan dengan koefisien jalur positif sebesar 0,293 dan $\mathrm{t}$ hitung sebesar 2,927 dan probabilitas sebesar $0,004<0,05$. Terdapat pengaruh positif transformational leadership terhadap job performance pada karyawan Pusdatin Kementerian Pertanian. Hal ini dibuktikan dengan koefisien jalur positif sebesar 0,470 dan thitung sebesar 4,834 dan probabilitas sebesar $0,000<0,05$. Terdapat pengaruh positif perceived organizational support terhadap job performance pada karyawan Pusdatin Kementerian Pertanian. Hal ini dibuktikan dengan koefisien jalur positif sebesar 0,407 dan t hitung sebesar 4,341 dan probabilitas sebesar $0,000<0,05$.

Work engagement memediasi hubungan antara transformational leadership terhadap job performance pada karyawan Pusdation Kementerian Pertanian. Hal ini dibuktikan dengan koefisien indirect effect sebesar 0,147 , nilai t hitung sebesar 2,466 dan probabilitas sebesar $0,014<0,05$.

Work engagement memediasi hubungan antara perceived organizational support terhadap job performance pada karyawan Pusdatin Kementerian Pertanian. Hal ini dibuktikan dengan koefisien indirect effect sebesar 0,180 , nilai t hitung sebesar 2,221 dan probabilitas sebesar 0,027<0,05.

Pimpinan Divisi Pusdatin di Kementerian Pertanian Republik Indonesia diharapkan dapat memberikan dorongan lebih pada karyawan dengan lebih banyak mengatakan hal-hal yang membuat karyawan bangga menjadi bagian dari organisasi, mengatakan hal-hal positif tentang unit kerja, dan mendorong orang untuk melihat perubahan lingkungan sebagai situasi yang penuh dengan peluang. Sebaiknya organisasi lebih peduli dengan opini dan masukan yang disampaikan oleh pegawai, dan memperhatikan kesejahteraan pegawai. Pimpinan bersedia memberikan bantuan ketika bawahan mengalami kesulitan dalam menyelesaikan permasalahan dan pekerjaannya, serta tidak mengambil keuntungan dari pegawai. Organisasi sebaiknya mempertahankan keterikatan kerja karyawan karena sudah terbukti jika work engagement memiliki pengaruh yang baik terhadap kinerja. Namun akan lebih baik lagi apabila organisasi dapat meningkatkan tingkat keterikatan kerja karyawan. Dengan beberapa upaya yang dapat dilakukan, seperti meningkatkan dalam memberikan reward dan pengakuan atas kinerja yang telah dilakukan, maka akan menimbulkan rasa kewajiban dalam diri karyawan dalam merespon reward dan pengakuan tersebut dengan lebih melibatkan dalam pekerjaannya. Diharapkan makin tinggi keterikatan kerja sehingga makin tinggi juga kinerja yang diberikan karyawan.

\section{REFERENSI}

Abed, F., \& Elewa, A. H. (2016). The Relationship Between Organizational Support, Work Engagement and Organizational Citizenship Behavior as Perceived by Staff Nurses at Different Hospital. IOSR Journal of Nursing and Health Science, 5(4), 113-123.

Al-Amin, M. (2017). Transformational Leadership and Employee Performance Mediating Role of Employee Engagement. North South Business Review, 7(2), 2840.

Arfat, Y., Rehman, M., Mahmood, K., \& Saleem, R. (2017). The Role of Leadership in Work Engagement: The Moderating Role of A Bureaucratic and Supportive Culture. Pakistan Business Review, 19(3), 688-705.

Arshadi, N., \& Hayavi, G. (2013). The Effect of Perceived Organizational Support on Affective Commitment and Job Performance: Mediating Role of OBSE. Social and Behavioral Science, 84, 739-743.

Babin, B. J., \& Boles J. S. (1998). Employee Behavior in a Service Environment: A Model and Test of 
Potential Differences Between

Men and Woman. Journal of Marketing, 62(2), 77-91.

Buil, I., Martinez, E., \& Matute, J. (2018). Transformational Leadership and Employee Performance: The Role of Identification, Engagement and Proactive Personality.

International Journal of Hospitality Management, 77, 6475.

Chandrasekara, W. S. (2019). The effect of transformational leadership style on employees Job satisfaction and job performance: A case of apparel manufacturing Industry in Sri Lanka. International Journal of Economics, Commerce and Management, 8(7), 385-393.

Creswell, J. W. (2009). Research Design: Qualitative, Quantitative, and Mixes Method Approaches. Newbury Park: Sage Publication.

Datche, A. E., \& Mukulu, E. (2015). The Effect of Transformational Leadership on Employee Engagement: A Survey of Civil Service in Kenya. Issues in Business Management and Economics, 3(1), 9-16.

Eisenberger, R., Huntington, R., Hutchison, S., \& Sowa, D. (1986). Perceived Organizational Support. Journal of Applied Psychology, 71(3), 500507.

Ghadi, M. Y., Fernando, M., \& Caputi, P. (2013). Transformational Leadership and Work Engagement: The Mediating Effect of Meaning in Work. Leadership \& Organization Development Journal, 34(6), 532550.

Ghozali, L., \& Latan, H. (2015). Structural Equation Modeling: Metode Alternatif dengan PLS. Semarang: Badan Penerbit Undip.

Hall, J., Johnson, S., Wysocki, A., \& Kepner, K. (2002). Transformational leadership: The transformation of managers and associates. EDIS, 2002(2).

Handoko, T. H. (2001). Manajemen Personalia dan Sumber Daya Manusia Edisi 2. Yogyakarta: BPFE.

Hayati, D., Charkabi, M., \& Naami, N. (2014). The Relationship Between Transformational Leadership and Work Engagement in Governmental Hospital Nurses: A Survey Study. SpringerPlus, 25(3), 1-7.

Hersey, P., Blanchard, K. and Johnson, D. E. (1996), Management of Organizational Behavior: Utilizing Human Resources, 7th ed., PrenticeHall, Englewood Cliffs, NJ.

Joorsara, M., Tajasob, K., \& Ahmadian, S. (2015). The Relationship among Leadership Style, Perceived Organizational Support, and Employees Job Performance in Iran Khodro Dissel Company. Science Journal, 36(6), 11381151.

Karatepe, O. M., \& Aga, M. (2016). The Effect of Organization Mission Fulfillment and Perceived Organizational Support on Job Performance The Mediating Role of Work Engagement. International Journal of Bank Marketing, 34(3), 368-387.

Kinicki, A., \& Fugate, M. (2018). Organizational Behavior: A Practical, Problem-Solving Approach. New York: McGrawHill Education.

Köse, A. (2016). The Relationship between Work Engagement Behavior and Perceived Organizational Support and Organizational Climate. Journal of Education and Practice, 27(7), 42-52.

Lai, F., Tang, H., Lu, S., Lee, Y., \& Lin, C. (2020).

Transformational Leadership and Job Performance: The Mediating Role of Work Engagement. SAGEOpen, 10(1), 1-11. 
Lu, C., \& Lin, C., (2014). The Effect of Perceived Culture Different and Transformational Leadership on Job Performance in Container Shipping Industry. Journal of Marine Science and Technology, 22(4), 463-475.

Manzoor, F., Wei, L., Nurunnabi, M., Subhan, Q. A., Shah, S. I. A., \& Fallatah, S. (2019). The Impact of Transformational Leadership on Job Performance and CSR as Mediator in SME. Sustainability, 11(2), 436-449.

Mathis, R. L., \& Jackson, J. H. (2002). Human Resource Management. Thomson Learning.

Motowidlo, S. J., \& Kell, H. J. (2013). Job Performance, Handbook of Psychology. Industrial and Organizational Psychology, 12(2) $82-103$.

Mustafa, A. M., \& Kanbur, A. (2018). Exploring The Relationship Between Perceived Transformational Leadership Behaviors and Work Engagement at Libyan School in Turkey. International Journal of Social Science and Humanities Research, 6(4), 1492-1500.

Nasurdin, A. M., Ling, T. C., \& Khan, S. N. (2018). Linking Social Support, Work Engagement and Job Performance in Nursing. International Journal of Business and Society, 19(2), 363-386.
Rafferty, A. E., \& Griffin, M. A. (2004). Dimension of Transformational Leadership: Conceptual and Empirical Extensions. The Leadership Quarterly, 15(3), 329354.

Rhoades, L., \& Eisenberger, R. (2002). Perceived organizational support: a review of the literature. Journal of applied psychology, 87(4), 698.

Rubel, M. R. B., \& Kee, D. (2013). Perceived Support and Employee Performance: The Mediating Role of Employee Engagement. Life Science Journal, 10(4), 25572567.

Saks, A. M. (2006). Antecedents and Consequences of Employee Engagement. Journal of Managerial Psychology, 21(7), 600-619.

Schaufeli, W. B., \& Bakker, A. B. (2004). Job Demands, Job Resource, and Their Relationship with Burnout and Engagement: a Multi-Sample Study. Journal of Organizational Behavior, 25(3), 293-315.

Wan, P., \& Saidin, K. B. (2018). A Study of Relationship between Perceived Organizational Support and Work Engagement of Administrative Staff in Newly-Established Universities of China. Journal of Social Science Research, 12(2), 2756-2763.

Yukl, G. (1998). Kepemimpinan Dalam Organisasi. Jakarta: Bhuana Ilmu Populer. 
